found at autopsy. A moderate to a high leukocytosis indie:ted a secondary sepsis; 93 of 108 eharted pneumonia cases without empyema showed evidence of sepsis.

'The reason for the marked cyanosis, observed elinically, was found to be extensive lung consolidation, which with the large amount of congulable inaterial found in the alveoli surrounding scattered arcas of consolidation must have made proper aëration of the blood cxtremely diffieult. The three cases of sudden death reported not only point out the extremes of the pathological process but are also of melieolegal importance.

\title{
CLINICAL ASPECTS OF PNEUMONIA FOLLOWING INFLUENZA, CAMP DODGE, IOWA, 1918.
}

\section{By Jaurs G. Carr, Captain, M.C., U.S.A., Calcago, ILlinols}

1. Tite statements and conclusions of this report are based on a study of the eharts of 274 patients and on personal experience during the epidemie. All the patients indudled in the formal review of 274 charts were admitted to the hospital in the first five days of the epidemic; we feel that this ensures a studly of the typienl cases, as the atypical cases are more likely to be seen as an epiclemic subsicles.

Of the 274 patients whose histories were studied 212 were whitc, 61 negro and 1 Indian; all were admitted to the hospital with influenza, except 4 ; in these 4 the history pointcd to a prior influenza, but pneumonia was present on admission.

The symptoms and course of the influenza were first studied. The onset is almost always sudden; in 100 charts the definite statement of a suclden onset is made; in 24 the onset is said to lave been gradual; but among these 24 mally were found in whom it appeared that the patient had not been quite wcll for a while, had suffered with a "cold," for instance, yet the definite symptoms of influenza lad appeared quite suddenly: morcover, even the charts that eontained no statement as to the abruptness of onset usually stated the listory in a way to warrant the inference of suddenness in onset. Finally, of the 274 patients only 30 stated that they lad been sick more than four days; 35 were admitted to the lospital within twentyfour hours of the first symptoms, 111 on the second day, 45 on the third and 17 on the fourth day.

Headaclie was the most common complaint; it was mentioned 206 times, often being spoken of as severe and the most distressing symptom. Cough was complained of in 194 eases; 3 times it was described as dry, 3 times as assoeiated witl a mucous or mucopurulcnt sputum; in 61 cases the couglı was claracterized as slight; 
than ten days; termination is by crisis in about 15 per cent. of the cascs.

4. There is a tendency to complications of a septie nature; purulent accumulations oceur in various situations; mediastinal abseesses, cmpyema, septie arthritis, muscular abscesses, otitis media have been seen; erysipelas may also be a complication.

5. Of uncertain etiology we have no rational method of treatment; the essential fcature, the bacteriological causative factor, must be determined before we can look forvard to specific therapy. Prophylaetic measures are now the most important; these should be carried out, in the light of the established faet that the disease is transmitted by contact infection. Once the pncumonia is established we must rely on general measures of treatment.

6. It is imperative that patients should not be discharged from observation too carly. Prophylaxis should include protection of the paticnt from exposure or undue activity for some time after apparent rccovery; in view of the fact that physical findings persist for some time after the general condition is good (definite evidence of considerable fluid was found in onc patient, after $h \geq$ hat been up and about several days), and in view of the further fact that activity of every sort seems to lessen resistance to the disease, too great carc can hardly be uscd to protect the convalescent patient from rccrudescence or complications.

7. The indications for aspiration of pleural effusions are, in our opinion, not clearly defined; at the height of the pneumonia the effusion has a marked tendency to recur, causing a rapid loss of fluid when large amounts of fluid are aspirated often; after the occurrence of the subcutaneous emphysema, already noted, and the failure to discover any cause for it, except bronchial and peribronchial necrosis, we felt that caution must be used to avoid injury to the lung by means of negative pressure employed to withdraw fluid; finally, there still remains the possibility that the pleural cftusion is at first a conservative process. The entire subject will be discussed in the report of Captain Manson, but we may state the indications, as they appeared to us; numbers 1 and 2 arc definite indications for interference.

(a) The discovery of frank pus, especially after the height of the pneumonic proeess had passed.

(b) Definite evidence of mechanical embarrassment on tlic part of the heart.

(c) Small effusions early are better left alonc; later if purulent they must be removed.

(d) Larger effusions even when displacing the licart had better bc removed by repeated aspirations of 500 c.c. or thereabouts at a time. 